\title{
ABUSE OF ISLAMIC LAW \\ AND CHILD MARRIAGE IN SOUTH-SULAWESI INDONESIA
}

\section{Kasjim}

Alauddin State Islamic University (UIN) Makassar, Indonesia email:kasjim.salenda@gmail.com

\section{Abstract:}

This article examines the prevalence of child marriage in South-Sulawesi Indonesia including people's perceptions and its factors contributing to child marriage and the use religion to justify their actions. They perceive child marriage as the marriage conducted prior to the age of 16 for woman and of 19 for man as stipulated in the Marriage Law No.1 of 1974, as well as the marriage before 'akil balig'. Various determinants for child marriage are cultural norms or values of 'siri' (shame) for family honour; family prestige and kinship; uneducated parents; economic burden for family and inconsistency in legislation. No religious teachings or Islamic Law clearly support the prevalence of child marriage because the purpose of marriage in Islam is to perform a happy and harmonious relationship among the couple. The use of the Prophet Muhammad's marriage to Aisha in the age of six as the fundamental basis for child marriage is unjustified.

Tulisan ini membahas kasus-kasus pernikahan anak di Sulawesi Selatan, termasuk persepsi masyarakat dan faktor-faktorpendukungnya diantaranya penggunaan dalil agama (Islam) untuk membenarkan tindakan tersebut. Masyarakat memahami pernikaban anak sebagaimana tercantum dalam UU Pernikaban No. 1 Tabun 1974 bahwa pernikahan anak terjadi pada usia dibawah 19 tahun bagi laki-laki dan 16 tahun bagi perempuan dan atau mereka yang belum akil balig'. Beberapa faktor dominan dalam 
pernikahan anak antara lain; norma adat lokal ('siri), kehormatan keluarga dan kerabat, orangtua yang kurang terpelajar, beban ekonomi keluarga dan ketidakekonsistenan penegakan peraturan. Pada dasarnya tidak ada ajaran Islam atau figh yang secara tegas mendukung pernikahan anak karena tujuan daripernikahan dalam Islam adalab kebahagiaan dan keharmonisan bubungan antar suami istri. Menggunakan rujukan pernikaban Nabi Muhammad dengan Aisyah saat usia enam tahun merupakan perkara yang tidak bisa dibenarkan.]

Keywords: child marriage, premarital sex, family honour, shame, Islamic law

\section{A. Introduction}

One of significant issues in the contemporary Indonesian Muslim society including international society is the practice of child marriage ${ }^{1}$ in which the marriage is conducted not accordance with the Marriage Law of 1974. This law is based largely on Islamic Jurisprudence and particularly applies to Muslim as the largest Muslim population in the world $(87.2 \%)$, with respect to marriage, divorce as well as religious charities (waqaf). According this Law, the minimum age for marriage is 19 for men while 16 for women. It is, therefore, whoever get marriage prior to this age may consider as 'child marriage'. ${ }^{2}$ It is therefore child marriage has been defined as the marriage before the age of 16 for women and of 19 for men.

Child marriage is often found in Indonesia as other countries in the world. This is likely due to overlapping between cultural or traditional beliefs (laws) and Islamic laws such as the preconception of premarital

${ }^{1}$ Linda Rae Bennett, "Early Marriage, Adolescent Motherhood, and Reproductive Rights for Young Sasak Mothers in Lombok", Wacana, vol. 15, no. 1 (2014), p. 66.

2 There are various description of being 'child' among Indonesian laws and legislations. It is considered child if their age prior to 18 years as stipulated in Child Protection Law, 23/2002; Workforce Law, 13/2003; Society Law, 12/1995; Human Rights Law, 39/1999; Pornography Law, 44/2008; Human Trafficking Law, 21/2007; Citizenship Law, 12/2006; Child Court Law, 3/1997; Notary Public Law (Child Witness), $30 / 2004$. 
pregnancy. ${ }^{3}$ Lindsey argues that it is difficult to differentiate between traditional customs and religious beliefs because they influence one another and both have influenced Indonesian law. ${ }^{4}$

The practice of child marriage among Buginese and Makassarese has been socially and culturally supported. They believe that the sooner the women get marriage the better in terms of economic and financial consideration as well as family honour (tudung kehormatan keluarga) for both the newly couple and the family. However, when they get marriage late or unmarried women, it is called 'their prosperities and luck is 'close and late' which means that it can be ashamed for family honour. It is also often that the community blame them as 'poor' and have negative perception of being unmarried women.

Moreover, as mostly Buginese and Makassarese are Muslim, they sometimes believe that child marriage is permissible dan justifiable because there is no clear Islamic teachings both from Quran and Hadith dictated about the minimum age of marriage, and it is merely on physical and biological aspects such as aqil baligh. They tend to seek normative texts for religious based which eventually claim for the truth of Islamic teaching. ${ }^{5}$ For them, women and men can get married if they have already got aqil baligh without considering of their age.

National Data of 2013 and 2015 shows that the prevalence of child marriage in Indonesia is high which was about 24 and 23 precent in 2014 and 2015 respectively. South-Sulawesi was categorized as 'Red Zone' for child marriage. The precentage of women getting marriage under the age of 16 in South Sulawesi was higher among Buginese communities compared to the Makassarese one. Wajo was the highest as it is of 29.19

${ }^{3}$ Susan Blackburn and Sharon Bessell, "Marriageable Age: Political Debates on Early Marriage in Twentieth-Century Indonesia”, Indonesia, vol. 63 (1997), pp. 107-41.

4 Tim Lindsey, "An Overview of Indonesian Law", in Indonesia: Law and Society, ed. by Tim Lindsey (New South Wales: The Federation Press, 2008), p. 3.

${ }^{5}$ For detail explanation of how Muslims have different approaches in understanding Islamix texts, see, Akh Muzakki, "Current Debates in the Post-Soeharto Indonesian Islam: Examining the Intellectual Base of Liberal and Anti-liberal Islamic Movement", Al-Jami'ah: Journal of Islamic Studies, vol. 45, no. 2 (2007), pp. 321-66; Komaruddin Hidayat, "Arkoun dan Tradisi Hermeneutika", in Tradisi, Kemodernan, dan Metamodernisme: Memperbincangkan Pemikiran Mohammed Arkoun, ed. by Johan H. Meuleman (Yogyakarta: LKiS, 1996), pp. 23-33. 
percent, followed by Maros and Barru where were about 27.41 and 27.04 percent recpectively. Similarly, Bone, Pinrang and Sidenreng Rappang were approximately $26.10,25.87$ and 25.65 respectively. On the other hand, the precentage of women getting marriage below 16's was lower in Makassarese societies such as Jeneponto was 21.30 percent and Gowa and Makassar were about 18.47 and 9.94 percent simoultanously. ${ }^{6}$

Data indicates that there is a connection between social, cultural and religious values and beliefs and the existance of child marriage in South Sulawesi. As Wajo and other Buginese districts are predominantly Muslim and have strong familial ties, they are likely to perform child marriage for social, cultural as well as religious reasons. Some may argue that it is hard to refuse the enggagement for men's family particularly from their close family to marry of their daughter. There will be significant impacts for such refusal like disharmony among family members. Another reason for child marriage is often related to the understanding of Islamic teachings as the Prophet Muhammad married to Aisha while she was in the age of nine.

However, other Makassarese communities tend to have lower precentage of child marriage in comparison with Buginese and this is possibly due to the urban and the needs for economic independencies among them. An interesting phenomenon occurs on child marriage in South-Sulawesi that although both ethnics are mostly Muslim but the reason for child marriage differs. In this context, this paper elaborates perceptions on child marriage, people's understanding in Islamic law with respect to child marriage and its challenges for such understanding as well as empirical evidences of child marriage in certain areas of SouthSulawesi.

\section{B. Perceptions of Child Marriage}

People may have different perceptions on child marriage depending on their background knowledge, social and cultural beliefs and values. Similarly, South-Sulawesi communities' perceptions on child marriage

${ }^{6}$ Indonesia is in the position of 37 th of child marriage in the world and as the second rank in Asia after Cambodian. See: Perkawinan Usia Anak di Indonesia 2013 dan 2015 (Jakarta: Direktorat Statistik Kesejahteraan Rakyat, BPS, 2016), pp. 20-2.; See also data from National Family Planning 2016 
differ and generally can be categorized into two as follows:

Firstly, child marriage is the marriage between men and women whose age is not compatible with Marriage Law No. 1 of 1974 in which women should be at least 16 years old while men are 19 years. This is relevant to the definition of child marriage in various countries. ${ }^{7}$ It can be seen that the majority of community and religious leaders including KUA members (office for religious affairs) acknowledge about such limitation of age but the question is that why they break the law. There are several reasons for that, namely 'to save family honour' due to the couple have involved in premarital sex as well as pregnancy prior to marriage.

Secondly, some people define child marriage as the marriage is allowed after achieving 'akil balig' indicating that women have had menstruation whereas men achieve adulthood as changing the voice, having dream followed by sperm, and changing psychologically and physically. In addition, they claim that women who have physically grown up, mature enough and have womenhood characteristics such as having capacities for taking cares of families and other domestic roles, they are permitted to get marriage even though this is againts Marriage Law No. 1 of 1974. Such community claims that physical development (subur) can be legally justified for child marriage. ${ }^{8}$

If men and women have achieved 'akil balig', so that they can get married even thought their age does not reach of 16's for women and of 19's for men. These communities claim that there is no clearly stated both in the Qur'an and hadith about the limitation of age, so it is not necessary to take Marriage Law No.1 of 1974 for marriage references. They are merely referred to Islamic resources which are Al-Qur'an and hadith, and they never consider about the importance of psychological and economical aspects for developing marriage relationships.

Muslim women living in rural areas have greater impacts of child marriage. ${ }^{9}$ Child marriage has significant implication for both women and

7 Annie Bunting, "Stages of Development: Marriage of Girls and Teens as an International Human Rights Issue”, Social \& Legal Studies, vol. 14, no. 1 (2005), pp. 17-38.

${ }^{8}$ Focus Group Discussion with Community and Religious leaders in Makassar and Gowa, October 2-3, 2015

9 S.M. Mostafa Kamal et al., "Child Marriage in Bangladesh: Trends and Determinants”, Journal of Biosocial Science, vol. 47, no. 1 (2015), pp. 120-39. 
Kasjim

their children. One of child marriage purposes is to prevent premarital sex as well as to preserve family honour. ${ }^{10}$ Some societies such as Indonesia believe that virginitiy is the most importance of human dignity, so that they prefer to marry off their children earlier if they have had a close relationship as well as to end trangressive sexual behaviour.

\section{Factors Contributing to Child Marriage}

Child marriage is currently a serious social problem which may have different natures and implications in many different countries, particularly in developing countries. Child marriage is a product of 'diasporic experience' and not 'traditional practice'. ${ }^{11}$ Noha Shawki envisages that child marriage is caused by various socio-economic and cultural circumstances such as poverty, cultural practices and culturallyrooted norms with respect to gender roles, the low social status of women and the low level of education. ${ }^{12}$ Women and men's education, women's job, georaphical location and religion play an important role in detemining child marriage. ${ }^{13}$

Similar phenomenon occur in child marriage in South-Sulawesi Indonesia. Various factors contributing to the prevalence of child marriage including cultural values shame (siri) for family honour; family prestige and kinship; uneducated parents; economic burden for family and inconsistency in legislation.

\section{Child marriage may result from cultural values shame (siri') for family bonour.}

They conduct child marriage if the children have committed something that are againts cultural and social values such as having intimate relationships which may lead to premarital sex, unwanted pregnancy as well as silariang (obduction or elopment). It is evident that

${ }^{10}$ Gavin W. Jones, Changing Marriage Patterns in Asia, ARI Working Paper Series, no. 131 (Singapore: NUS, 2010), p. 12.

${ }^{11}$ Anne Phillips and Moira Dustin, "UK Initiatives on Forced Marriage: Regulation, Dialogue and Exit”, Political Studies, vol. 52, no. 3 (2004), pp. 531-51.

${ }^{12}$ Noha Shawki, "Norm-Based Advocacy and Social Change: An Analysis of Advocacy Efforts to End Child Marriage”, Social Alternatives, vol. 34, no. 4 (2015), p. 58.

13 Kamal et al., "Child Marriage in Bangladesh", pp. 120-39. 
young girls and boys have an intimate relationship through the extensive communication technologies like celluler phone, internet access for free access youtube and videos containing uneducated contents (sex performances). They eventually may immitate what they have seen on such devices and reluctant to attend schools. If the parents identify the wrong behaviour of their children, they prefer to marry off their children. Similarly, the parent sometimes forces marriage for their daughter with a man who is mature and older when they see that they are having close relationship. For this society, conducting child marriage with someone who have the same age or older is better than they do something culturally and socially wrong which may lead shame (siri'). Bennett highlights that child marriage as a result of adolescent pregnancy for Indonesian are shameful. ${ }^{14}$ For women including their kin, getting pregnant before marriage is the most shameful in their life and the father or brother is more likely to stand for preserving their shame (siri'). Killing sometimes may apply.

Performing such attitudes is considered as shame (siri'). In this context, men are mostly presumed to be responsible for preserving and exercising 'siri'. According to Makassar tradition, men, particularly the father or the oldest son, are the most influential people in the family with respect to social and economic responsibilities. ${ }^{15}$ Men uphold important familial roles, which include controlling and monitoring the family, especially with respect to 'family honour' and the concept of 'shame' $\left(\text { siri' }^{16}\right)^{16}$ as well as decision making with respect to accepting or refusing

${ }^{14}$ Bennett, "Early Marriage, Adolescent Motherhood, and Reproductive Rights for Young Sasak Mothers in Lombok", p. 68.

15 See, Abdul Latif, "Politik Perkawinan dan Pola Pewarisan Kekuasaan di Konfederasi Ajatappareng, Sulawesi Selatan”, Paramita: Historical Studies Journal, vol. 24, no. 1 (2014), pp. 78-91.

${ }^{16}$ Abdullah clarifies that there are two types of siri' namely negative or destructive and positive or constructive. Negative siri' indicates any action manifested to defend family honour in the society and this is mostly related to physical and financial loss. The positive one, however, implies motivations or spirits such as optimism, honesty, hard work in daily life. Siri' is considered as central to Makassar people's identity and honour which aims to control personal and communal attitudes in order to achieve a harmonious society. Various terms are used to identify their siri' including masirika/ siri-sirika ( I am ashamed to do that) and napasirikka (I am ashamed of his/her action). Hamid Abdullah, Manusia Bugis Makassar (Jakarta: Inti Idayu Press, 1985), pp. 57-9. 
a marriage proposal for female members of the household. Men may be killed or imprisoned for complying with such roles. ${ }^{17}$

In relation gender roles, women are often controlled and managed to preserve family honour. Women are presumed by various social and cultural images such as 'household supervisor' (pa'jaga billik), 'living diamond' (permata hidup) as well as 'family property' (milik keluarga). As a household supervisor, it is prescribed that a woman's primary responsibility is in the domestic spheres. To achieve such roles, it is common that the oldest daughter is socialized to undertake domestic roles including managing the household finance. Moreover, a Makassar woman is sometimes referred to as a 'living diamond' which literally means a respected and honoured person both in the family and society. The woman is expected to be a symbol of family prestige, to achieve the status of a 'good woman', and she should not undermine family honour pertaining to the siri' preconception.

Abu Hamid (an anthropologist from Makassar) elaborates that indicators of being 'good' include not engaging in adultery or premarital behavior (zina), marriage without family consent, or 'bride abduction' (silariang). Silariang refers both to women agreeing to elope with men, and the practice (or threats) by unscrupulous men of taking a woman without her or her family's consent. Bride abduction is the serious consideration of siri. ${ }^{18}$ According to Makassar traditional norms and rules, women should be controlled and supervised by male kin to ensure they do not elope. ${ }^{19}$ Controlling and supervising women to prevent them from being siri' is not just in the case of elopement but also of other issues such as engaging promiscuous behaviour.

Abdullah and Abu Hamid argue that there are at least three reasons for silariang. The parents or guardians of the couple disagree on the amount of bride price (uang panai); the woman's family refuses to recognize or sanction an engagement or betrothal; or the woman's social status is higher than the man's. ${ }^{20}$ It is also evident that pregnancy

17 Ibid., pp. 130-1.

${ }^{18}$ Ibid., pp. 37-8; Abu Hamid, Syekh Yusuf Makassar: Seorang Ulama, Sufi dan Pejuang (Jakarta: Yayasan Obor Indonesia, 1994), p. 32.

19 Abdullah, Manusia Bugis Makassar, p. 131.

20 Ibid., pp. 37-8; Hamid, Syekh Yusuf Makassar, pp. 32-3. 
prior to marriage may lead to silariang if the bride's family is reluctant to support the marriage. For the couple, silariang could be the best solution to legitimate the relationship even though this constitutes siri'. The impact of such siri' may lead to the killing of both the man and woman, and this is a socially and culturally acceptable form of atonement for causing siri' (family dishonour). However, currently, this phenomenon occurs rarely, particularly in urban areas, because negotiations are given priority. Sometimes, monetary payment is negotiated as compensation so that the couple can return and live without conflict in the family or in the community.

In terms of 'silariang' (obduction or elopment) in child marriage cases, there have been similar arguments for that including pregnancy prior to marriage and the parents disapprove for their marriage due to different social economic background and disagreement about the pride price (uang panai). ${ }^{21}$ It is therefore, the parent and family do not involve in silariang process. However, if the woman is pregnant and no man is responsible for her pregnancy, so the parent or family has to have an initiative to find a suitable man to marry her for family honour. This marriage initiation is to prevent of giving birth without legal husband. This is locally called as pattongko' siri'. This kind of marriage purpose is just to achive social and marital identity rather than looking for the biological father of the baby. Silariang and pattongko' siri have not been social and culturally accepted in South Sulawesi. It should be noted that pattongko' siri is also not permitted in Islamic teachings because biological father has to marry the woman and should be conducted after giving a birth.

Another cultural assumption of Makassar women is as family property. A prominent woman activist, Andi Baso and her colleagues illustrate that the meaning of 'family property' likens women to other assets. This means that women are 'owned' by the family and if someone 'takes' them without family permission, this is considered a serious offence, in the view of family members such as in the case of 'bride

21 Focus Group Discussion with Community Leaders and Religious Leaders, 2-3 October 2015. 
abduction' (silariang). ${ }^{22}$ Other cultural attitudes with respect to women as 'family property' are in relation to 'bride price' (uang panai) which usually refers to the groom's family obligation to pay for the marriage celebrations. ${ }^{23}$ Men bring such payments to marriage, and the amount depends on an agreement being reached between the respective families of the bride and groom. Both sides engage in intensive negotiation to finalise how much the groom should pay, and marriage is sometimes delayed or even cancelled if consensus cannot be reached. Thus, the practice of child marriage is culturally and socially preferable to avoid unwanted pregnancy and 'bride abduction' (silariang) as they constitute shame (siri').

\section{Family prestige and kinship is likely associated with the prevalence of child marriage.}

Child marriage often occurs when a girl is engaged by a man who is either economically advantaged, high social stratification, religious or close kinship. It is difficult to refuse such engagement while at the same time the bride family is proud of and honour for that bless. They should be happy as a kind of destiny (rezeki and untung). Low economic families tend to marry their daughter to relieve economic responsibilities, but in most cases they marry their daugher with someone who has similar clan to strengten their kinship ties. It constitutes siri' to refuse an engagement from close family and the parent often marry them without their daughter consent.

My friend who experienced child and arranged marriage got marriage in the age of 14 but the marriage lasted only within four months. She did not know and never keep in touch with her husband as she just obeyed her parent wishes to marry one of her close family. Her parent tried to stimulate her to love her husband but she could not do it. So, she applied for divorce and she eventually continued her study until university and got

22 Zohra Andi Baso, DA Tina, and S. Haerani, Kekerasan Terbadap Perempuan: Menghadang Langkah Perempuan, ed. by Faturochman (Yogyakarta: Pusat Studi Kependudukan dan Kebijakan, Universitas Gadjah Mada; Ford Foundation, 2002), p. 104.

23 In this context, the bride's family will estimate the total cost of the marriage celebration including ceremonials, food and other expenditures. This family suggests a certain amount to be paid by the groom's family, but the groom's family will often haggle. 
married with her beloved one. Now, she enjoys her job and new family. ${ }^{24}$

In term of family prestige of child marriage, parents often worry about the delay of their children marriage. There is cultural belief that if a woman does not get marriage in the age of 30s it means she is not 'useful'-tidak laku (local term is tau lolo bangko'), while a man does not get marriage over 25 years will be called as 'someone does not have money' (local term is tau tena doina). It indicates that marriage in South-Sulawesi tend to be like 'economic transaction'in which a woman gets marriage by such age named as tidak laku (not sold or not useful) where as a man relates him as having no money to pay uang panai (bride payment). Marriage is often postponed or cancelled due to insufficient of this bride payment. Also, the age of man and woman differs because man is culturally obligated to make an enggagement while woman is waiting to be enggaged. Men should be more active and women are passive.

Therefore, Makassarese and Buginese prefer to marry their children before this age for family prestige. It is often found that the family is proud of and makes comments that:

'alhamdulillah lakumi anakeku, adami jodohnya'

thanks God that my daughter is 'sold' and finds her partner.

Interestingly, it is said that the family may go to wicth (dukun) to get infomation about the marriage possibilities for their children. ${ }^{25}$

The contraproductive responses from family related to marriage for their daughter. They express happily when she gets married soon, and they also worry if their daughter is a bit late in marriage. Thus, social and cultural norms and values are a key driver of child marriage supported by parents, family and even community members. They should work collaboratively to identify and criticize unsupported norms in preventing child marriage.

\section{Child marriage may result from uneducated parents.}

Uneducated parents are more likely to marry their children as they are so pragmatic. They have traditional and patriarchal way of thinking that women's roles are domestic carers. Their responsibilities are raising

24 Interview with a victim in Barru-South Sulawesi, 25 April 2016.

25 Interview with a female Judge, living in Wajo- South Sulawesi, 22 April 2016. 
children, caring for the family and the elders, cooking and managing the house. To perform such responsibilities, it is not necessary to attend high education, so child marriage occurs if someone enggages their daughter. On the other hand, men roles are in the farm. For them, working in the farm is lack of using technological advances and does not need certain skills. When the man has had traditional knowledge for farming activities, this is sufficient and getting marriage earlier is culturally permitted.

Uneducated parents also marry their children in the young age for economic burden. They can relief from economic challenges when the children get marriage including a bride price (dowry). ${ }^{26}$ All economic and psychological responsibilities are handed over by their spouse regardless of their capacities in doing so. This traditional and patriarchal thinking has certainly brought about their family welfare and economic empowernment as they are difficult to achieve it. Low education and limited skills are impossible for them to access professional jobs and to upgrade their standard of living. For this reason, poverty continues to exist within this family. Davis et al supports this argument acknowledging that women who are low educational opportunities and experience child marriage have negative implications in 'their income potential, increasing their vulnerability and reinforcing their poverty, and reducing their communities prospects for economic development'. ${ }^{27}$ One that could be done is that advocacy and dissemmination on the impacts of child marriage should intensively conducted in all level of communities.

\section{Inconsistent legislation contributes to child marriage}

According to Marriage Law No.1 of 1974 (chapter 7: 1), marriage is permitted at the minimum age of 19 for men and of 16 for women. Then, chapter 7:2 dictates that marriage prior to these ages is allowed by taking dispensation from Court or other institutional officers appointed by parents or guardian of men or women. These two articles offers double standard of the age limitation of marriage while the later

${ }^{26}$ Joar Svanemyr et al., "Preventing Child Marriages: First International Day of the Girl Child "My Life, My Right, End Child Marriage", Reproductive Health, vol. 9 (2012), pp. 31-3.

27 Anthony Davis, Claire Postles, and Giorgiana Rosa, A girl's right to say no to marriage: Working to end child marriage and keep girls in school, ed. by Anna Brown (Woking: Plan International, 2013), pp. 40-5. 
article permits people to submit their application for dispensation to conduct child marriage without clearly stated various reasons for taking dispensation. Empirical studies show that there are many reasons for applying dispensation in the courts such as premarital pregnancy, silariang (abduction or elopment), intimated relationship between young girls and boys, adultery prevention, forced or arranged marriage for preserving siri' (shame and family honour).

It should be noted that the dispensation article must clearly describe certain requirements for marriage dispensation or suspend it. The Indonesian Government should take this issue into account if they seriously eliminate the exidence of child marriage. This concludes that Marriage law provides opportunities for people to conduct child marriage.

Despite the weakness of Marriage Law itself, apparatus or government officers, particularly KUA tend to support the practice of child marriage if the spouse are outsiders. This means that the child marriage couple does not have permission to proceed their marriage within their own geographical area, they propose KUA officers in other areas by upgrading their age. The new KUA officers believe and accept their proposal without further clarification. They also break regulation that marriage should be conducted on their territories. There is evident that 'Kampung Pisang' (the name of village in South-Sulawesi) always 'help' people to finalise the marriage couple if they have problems in their own area. So, no strict punishment both for perpetrators and KUA officers for unlawful conducts is applied.

\section{Correlation Between Those Factors and the Practice of Child Marriage}

It generally indicates that there is a close interconnection between the prescribed factors and the practice of child marriage in SouthSulawesi. Preserving cultural and social values of siri (shame) and family honour is essential rather than having children who have premarital sex, pregnant outside legal marriage as well as silariang (obduction). Free courtship as well as free sex are shameful and are considered moral decay for Indonesians. ${ }^{28}$ In this context, child marriage occurs to prevent

${ }^{28}$ Claire Harding, "The Influence of the 'Decadent West': Discourses of the Mass Media on Youth Sexuality in Indonesia Workers", Intersections: Gender and Sexuality 
premarital marriage (adultery) or if the girl is pregnant before marriage or silariang (obduction). Before committing such wrong behaviours, marriage is the best solution for children even their age does not comply with the marriage standard.

This is relevant to other research findings conducted in other areas in Indonesia such as Lombok (West Nusa Tenggara), ${ }^{29}$ Mamuju (West Sulawesi) and Madura. They highlight that child marriage is mostly related to cultural norms and values of being 'siri' (shame) and family prestige when the child may involve in close relationship (premarital sex); pregnancy before marriage and 'kawin lari' (silariang). A girl from Lamongan-East Java describes her marriage because of pregnancy prior to marriage. Another girl from Sumenep Madura acknowledges that her parents marry off her for two reasons namely to pay her parents' bill and they worry that she may get premarital sex and pregnant which deteriorates family honour and shame. ${ }^{30} \mathrm{~A}$ girl also envisages that she proposes marriage to her parents because she understands that religion (Islam) does not allow to have a boy friend and is afraid of misbehave. They finally got marriage even though they did not stay in one house. ${ }^{31}$ In terms of 'kawin lari' (silariang/ Makassar; merariq/Sasak), a girl in Lombok has agreed to take a way from her family by her boy friend (merariq). In doing so, the parents have to conduct marriage. ${ }^{32}$ These

in Asia and the Pacific, no. 18 (2008).

${ }^{29}$ Maria Platt, "'It's Already Gone Too Far': Women and the Transition into Marriage in Lombok, Indonesia", The Asia Pacific Journal of Anthropology, vol. 13, no. 1 (2012), pp. 76-90.

${ }^{30}$ Lies Marcoes, "Indri: Tidak Mau Nikah Maunya Sekolah", in Kesaksian Pengantin Bocah, ed. by Lies Marcoes and Fadilla Dwianti Putri Jakarta: Yayasan Rumah Kita Bersama, 2016), pp. 68-9, 225; Yusuf Hanafi, "Pengendalian Perkawinan Dini (Child Marriage) Melalui Pengembangan Modul Pendidikan Penyadaran Hukum: Studi Kasus pada Masyarakat Subkultur Madura di Daerah Tapal Kuda, Jawa Timur", PALASTREN Jurnal Studi Gender, vol. 8, no. 2 (2016), pp. 399-421.

${ }^{31}$ Qanita Windyanggiva, "Rani: Menikah Karena Dilarang Pacaran”, in Kesaksian Pengantin Bocah, ed. by Lies Marcoes and Fadilla Dwianti Putri (Jakarta: Yayasan Rumah Kita Bersama, 2016), p. 199; Bennett, "Early Marriage, Adolescent Motherhood, and Reproductive Rights for Young Sasak Mothers in Lombok”, p. 74.

32 Lies Marcoes and Fadilla Dwianti Putri, "Yunita: Menikah Karena Capek Bantu Ibu", in Kesaksian Pengantin Bocah, ed. by Lies Marcoes and Fadilla Dwianti Putri (Jakarta: Yayasan Rumah Kita Bersama, 2016), pp. 143-4. 
various reasons for child marriage are common cases in Indonesia and can be found in other countries. ${ }^{33}$ It is important to note, the parents (family) tend to provide 'a shock therapy' for marrying off their children as a result of such misconduct instead of questioning and criticizing their way of caring, educating and supervising their children. In specific cases of silariang (Makassar) or merariq (Sasak), children often enforce 'a shock therapy' to parent to get marriage early.

In addition, strengthening familial ties or kinship, economic imperative and the prevalence of child marriage is interconnected. In South-Sulawesi the parents force their children to marry for kinsip and economic reasons. Some parents prefer to arrange marriage with someone either who is close family or friends in order to achieve strong family or who has high social stratification. Ideally, marriage should not enforced, but everybody can have independent choice and have rights to access to marriage education prior to marriage, so that they can perform a healthy relationship. ${ }^{34}$

For economic imperative, low economic parents tend to marry off their children for at least two reasons which are improving economic fulfilments and releave from economic burdens and tranferring economic responsibilities towards her husband. This likely occurs on uneducated parents. Shinta Nuriyah also agrees that low economic families tend to marry off their children for economic reason in which the husband can take over such economic responsibilities. ${ }^{35}$ As previously described, a girl has been forced to marry for paying the parent's bill. Child marriage actually does not improve economic condition and break the 'cycle of poverty' but it worsen the girls' conditions as they do not have access to education and in turns access to employment including economic and social costs. ${ }^{36}$

33 Jones, Changing Marriage Patterns in Asia, p. 4.

${ }^{34}$ Susan L. Brown, "Marriage and Child Well-Being: Research and Policy Perspectives", Journal of Marriage and Family, vol. 72, no. 5 (2010), p. 1061.

${ }^{35}$ Shinta Nuriyah Abdurrahman Wahid, "Perkawinan Anak: Reinterpretasi Teks untuk Pemenuhan Hak Anak Perempuan", Paper Presented in Workshop Girls Voices: Building A Community of Practice to End Child Marriage in Indonesia, Jakarta 29 November 2016, p. 4

36 Minja Kim Choe, Shyam Thapa, and Sulistinah Achmad, Early Marriage and Childbearing in Indonesia and Nepal, East-West Center Working Papers, no. 108-15 
Finally, there is significant correlation between legislation inconsistency and the prevalence of child marriage. Although parents as well as government apparatus realize that child marriage break the Law No. 1 of 1974, they allow to get dispensation from the Religious court. This is a double standard of the Indonesian legislation. Also, they should take into account that they go against other legislations such as Law No.23 of 2002 on the Protection of the Children Rights and Law No. 23 of 2004 on Domestic Violence. ${ }^{37}$ Islamic Court judges, particularly the female ones acknowledge that there is a significant factor for the increasing in the number of child marriage is the availability of dispensation. KUA officers (Religious Administration Office) have no power to refuse or cancel the child marriage if the dispensation letter is available. Although this legislation has been introduced in 1974, the extensive application of dispensation in South-Sulawesi has substantially grown since 2010. ${ }^{38}$ This certainly indicates that the Indonesian government does not seriously accommodate women's welfare and needs in particular as they suffer more due to child marriage. Inconsistencies in Indonesian legislations with respect to marriage, polygamy are clear, ${ }^{39}$ including the lack of commitments of Indonesians to obey such legislations.

Dispensation is widespread in Indonesia. Current data shows that women applying for dispensation between 14-15 years old while age of 17-19 for men. The majority of Indonesian apply for dispensation is due to having an affair or dating, akil baligh, ready for marriage, spouse economic independent, disapproval from KUA. ${ }^{40}$ In comparison, there has been a significant increase in the number of marriage dispensation from 2009 to 2014 in Jepara Central Java, and this becomes a third rank after divorce initiated by wives (Cerai Gugat) and divorce initiated

(Honolulu: East-West Center, 2001).

${ }^{37}$ See: Euis Nurlaelawati, "For the Sake of Protecting Religion: Apostasy and its Judicial Impact on Muslim's Marital Life in Indonesia", Journal of Indonesian Islam, vol. 10, no. 1 (2016), pp. 89-112.

${ }^{38}$ Interview with KUA officers, October, 2-3 \& Judges, 22 April 2016.

${ }^{39}$ Adriaan Bedner and Stijn van Huis, "Plurality of marriage law and marriage registration for Muslims in Indonesia: a plea for pragmatism", Utrecht Law Review, vol. 6, no. 2 (2010), pp. 175-91.

40 "Pernikahan Dini Jadi Penyumbang Tingginya Kematian Anak dan Ibu", Republika (21 Apr 2016). 
by husbands (Cerai Talak). It is 90 percent of them that have sexual intercourse without legal marriage, of 80 percent are pregnant. ${ }^{41}$ This phenomenon may exist in other parts of Indonesia as Jones clearly stated that child marriage seems acceptable in Indonesia for several reasons such as preserving family honour, parents and officials' refusal to have age limitation for marriage as well as not availability of valid birth certificate. ${ }^{42}$ The purpose for dispensation is not only to legally approve child marriage but also to avoid unregistered marriage for the couple which has significant impacts both women and their children. ${ }^{43}$ It is, therefore, the Indonesian government has provided double standards which likely provide a new of way of discrimination against women in particular.

\section{E. Misleading in Understanding Islamic Law and Its Responses}

Islamic law or sharia is often used by some Muslims to justify their actions both for private and public cases such as violence and other means. ${ }^{44}$ This includes in child marriage. In the case of South-Sulawesi, there are at least two significant arguments to permit child marriage which may result from literal understanding of Islamic teachings or Islamic law, namely no clear message from the Qur'an and Hadith with respect to the age of marriage and follow the practice of the Prophet Muhammad's marriage to Aisha. Although few people highlight these arguments, it needs to respond properly.

Some Muslims argue that Islam does not clearly dictate about the age of marriage and consequently tend to use fiqih to refer this issue. According to fiqih, marriage is allowed as long as both men and women

41 Ibid.

42 Jones, Changing Marriage Patterns in Asia, p. 12; Gavin W. Jones and Wei-Jun Jean Yeung, "Marriage in Asia", Journal of Family Issues, vol. 35, no. 12 (2014), pp. 1567-83; Ariane J. Utomo, "Marrying Up? Trends in Age and Education Gaps Among Married Couples in Indonesia", Journal of Family Issues, vol. 35, no. 12 (2014), pp. 1683-706.

${ }^{43}$ Thriwaty Arsal, "Woman's Position in Undocumented Marriages", Komunitas: International Journal of Indonesian Society and Culture, vol. 6, no. 1 (2014), p. 29.

${ }^{44} \mathrm{Al}$ Makin, "Islamic Acehnese Identity, Sharia, and Christianization Rumor: A Study of the Narratives of the Attack on the Bethel Church in Penauyong Banda Aceh", Journal of Indonesian Islam, vol. 10, no. 1 (2016), p. 7. 
have achieved the criteria of akil baligh. ${ }^{45}$ Ulama of South-Sulawesi argues that woman is allowed to get marriage after menstruation (akil baligh) even though their age does not reach minimum age of marriage according to Marriage Law No. 1 of 1974 because the government also provides marriage dispensation. ${ }^{46}$ Criteria of 'akil baligh' is textually understood as physical development of being adulthood such as initial menstruation for women and having a dream with sperm. Schools of Mazhab including other Muslims are likely to understand the initial stage of human responsibilities of their deeds with the permission of marriage.

A well-known religious man, Syekh Puji, married to a 12 years old woman, Lutfiana Ulfa in 2008, resulted in many criticism from Children welfare activists, the Minister for Religious Affairs, and women activists but he confidently argued that nothing wrong with the marriage. Some people supported him as they refer to textual Islamic teachings. ${ }^{47}$ Another case of child marriage occured in Timbuseng and Pattalassang Gowa of South Sulawesi 2013 where an Islamic high school girl got marriage in the age of 15 and her parents justified the marriage because she already had menstruation. ${ }^{48}$ This shows that people often use religion to justify their marriage.

However, other ulama of South-Sulawesi clarify that child marriage cannot be justified in Indonesia based on fiqih understanding for several considerations. Firstly, fiqih in Indonesia is merely for theoritical (discussion) not for implementation because Indonesia has stipulated laws with respect to the age of marriage. Indonesian Muslim must follow such laws not fiqih. He strongly urges that child marriage is illegal (tidak sah) and this is the 'Indonesian Islamic Law' ${ }^{49}$ This progressive idea seems

${ }^{45}$ Mukti Ali et al., Fikih Kawin Anak: Membaca Ulang Teks Keagamaan Perkawinan Usia Anak-Anak, ed. by Lies Marcoes and Roland Gunawan (Jakarta: Yayasan Rumah Kita Bersama, 2015), pp. 96-7.

${ }^{46}$ Interview with Ulama (KH. B) in Makassar, 16 November 2016.

47 Nurum Mukharum Mawan, "Mengapa Kalian Ingin Memisahkan Kami? Cerita Cinta Syekh Puji-Lutfiana Ulfa”, Cahaya Sura (6 Nov 2008), https:/ / cahayasura. wordpress.com/2008/11/06/mengapa-kalian-ingin-memisahkan-kami-cerita-cintasyekh-puji-lutfiana-ulfa/, accessed on 13 August 2016; "Balada Syekh Puji dan Ulfa", Gaulislam, www.gaulislam.com/balada-syekh-puji-dan-ulfa, accessed on 13 August 2016.

${ }^{48}$ Interview with a female Religious Counsellor, Makassar, 12 August 2016.

${ }^{49}$ Interview with Ulama (MUA) in Makassar, 02 November 2016. 
challenging common understanding of child marriage among Muslims in Indonesia. Secondly, referring to the fiqih understanding of child marriage it can endanger the life of the girls in particular and the society in general. When the girl gets menstruation in the age of 11 for example, then she allows to get marriage in the such young age. She eventually have health and psychological problem. Marriage should consider medical, religious, sociological and psychological aspects of the girl and including the child. ${ }^{50}$

This argument is consistent with empirical findings that child marriage may have health problem such as vaginal infection including the death of both mother and child. In addition, Nour argues that child marriage likely leads to health implications on women and their children such as Sexually Transmitted Desease (STDs), cervical cancer, malaria, maternal and child death during labour and obstetric fistulas. ${ }^{51}$ They also suffer unintended pregnancy, preterm delivery, low birth weight babies of delivery, fetal mortality and family violence. ${ }^{52}$

Another well-known ulama of South-Sulawesi emphasizes that Muslims do not merely refer to fiqih understanding in the marriage but psychological development is more important to consider as more new marriage couples in the contemporary society get divorce. ${ }^{53}$

Regarding to these arguments, ulama of South-Sulawesi disagree with the practice of child marriage by referring to fiqih understanding and Muslims have to take into account of child marriage impacts on women, their offspring as well as the wider society. Islamic teachings always encourage Muslim not to take a risk in all actions and prioritize on benefits (take maslahah, avoid mafsadah).

The second consideration in fovour of child marriage is the information of the Prophet Muhammad marriage to Aisha when she was 6 or 9 years old. This has been culturally and socially internalized within Muslims. Muslims mostly refer to hadith narrated by Aisha and

50 Interview with Ulama (MUA) in Makassar, 02 November 2016; Ulama (GHA) in Makassar, 15 November 2016; Ulama (ARF) in Makassar, 15 November 2016;

${ }^{51}$ N.M. Nour, "Health Consequences of Child Marriage in Africa", Emerging Infectious Disease journal - CDC, vol. 12, no. 11 (2006), pp. 1644-9.

52 K.G. Santhya, "Early marriage and sexual and reproductive health vulnerabilities of young women: a synthesis of recent evidence from developing countries", Current Opinion in Obstetrics and Gynecology, vol. 23, no. 5 (2011), pp. 334-9.

53 Interview with Ulama (KH.S) in Makassar, 18 November 2016. 
Kasjim

docummented in Bukhari and Muslim Books:

Aisha stated that the Prophet Muhammad married me when I was six years old and lived with him when I was nine (9). She said: When we arrived in Madina, I suffered fever for one month. My hair reached my shoulder. Then Ummu Ruman came and found me playing with my friends. She took me home and there were a lot of Muslim women. They make me up and surprisingly I saw the Prophet Muhammad. ${ }^{54}$

There are two different responses in understanding this hadith from hadith scholars in South-Sulawesi. First, one states that it is allowed to get marriage in the age of 9 as Aisha did. ${ }^{55}$ Second, this hadith must be critically examined either from historical evidence or content analysis (matan)..$^{56}$

It is also evident that although some Muslim use this hadith as a reference and is found in Bukhari and Muslim's Book, it does not mean that this is certainly valid and can be automatically used as a reference. According to Ibnu Hajar al-Asqalani, there are at least two weaknesses of this hadith, namely the question of rawi (transmitter) and a historical evidence. Hisyam bin Urwah, one of transmitters, transmitted this hadis after he was living in Iraq in the age of 71 . Ya'qub bin Syaibah argued that almost all hadith were transmitted by Hisyam bin Urwah before moving to Iraq is valid but not vice versa. In addition, Malik bin Anas refused this hadith. ${ }^{57}$

A historical evidence shows invalidity of this hadith. Al-Thabari argues that all Abu Bakar siblings gave birth before 610 (A.D). If the prophet Muhammad married to Aisha around 620 (A.D) it means that Aisha was at the age of 10 and lived with her of about 13. Ibnu Hajar al-Asqalani supports this with another evidence that Asma binti Abu Bakar lives about 100 years old and passed away in 73/74 (A.D.). This means that she was around 27/28 years when she did hijra, so Aisha was also about 17/18 during hijra and of course she lived with the Prophet

${ }^{54}$ Muhammad ibn Ismā̄îl Bukhārī, Shahih Bukhari, vol. v (Beirut: Dar al-Fikr, 1994), p. 238.

${ }^{55}$ Interview with Ulama/Hadith Scholar (AAS) in Makassar, 16 November 2016.

${ }^{56}$ Interview with Ulama/Hadith Scholar (ARF) in Makassar, 16 November 2016.

${ }^{57}$ Aḥmad ibn 'Alī Ibn Hajar al-'Asqalānī, Tahz̨ib at-tahz̨ib, vol. 2 (Beirut, Lubnan: Dar Sader, 1968), p. 50. 
Muhammad was approximately $19 / 20$ years old. ${ }^{58}$

Thus, this hadith is substancially contrary to the historical evidence, and it eventually cannot be acceptable as a reference as well as the transmitter involved in this hadis is weak. The hadith constitutes the Prophet Muhammad Marriage to Aisha in the age of 6 is invalid (dha'if).

Hadith scholar also highligths the content of the hadith should incorporate with another hadith dictating about marriage with fertile and powerful women. This means that psychologically strong, responsible and independent women are taken into a priority. ${ }^{59} \mathrm{It}$ is, therefore, that both Islamic resources (Al-Quran and Hadith) and Muslim scholars suggest to avoid child marriage.

\section{F. The Contextualization of Child Marriage, Islamic Law and Human Rights}

As described earlier in this article, there has been contradictory perceptions of child marriage between progressive and radical or tekstual Muslims. It is essential to note that child marriage should be seen in the broaden context, especially for progressive Islam as well as Human Rights.

The society including some women do not acknowledge that child marriage is actually against Islamic teachings and human rights. As child marriage has significant impacts on both women and children such as sexual assault, high maternal and child mortality and Sexually Transmitted Diseases (STDs), ${ }^{60}$ as well as domestic violence ${ }^{61}$ and divorce, it is important to rethingking of new paradigm for synergizing Islamic law and human rights to prevent it.

Moreover, from Human Rights' perspective, child marriage is a serious part of child abuse with respect to the rights for education and

${ }^{58}$ Abu Ja'far Muhammad bin Jarir Al-Thabari, Ta'rikh al-Rusul wa' Muluk, vol. IV (Egypt: Darul Ma’arif), p. 172; Ibn Ḥajar al-'Asqalānī, Tahzib at-tahzib, 2: 654.

${ }^{59}$ Interview with Ulama/Hadith Scholar (ARF) in Makassar, 16 November 2016.

${ }^{60}$ Geetanjali Gangoli, Melanie McCarry, and Amina Razak, "Child Marriage or Forced Marriage? South Asian Communities in North East England”, Children \& Society, vol. 23, no. 6 (2009), p. 419.

${ }^{61}$ Santhya, "Early marriage and sexual and reproductive health vulnerabil...", pp. 334-9. 
employment. Davis et al radically claim as 'part of slavery'. ${ }^{62}$ The girls have no rights to have their own independent choice either to marry, to have education or to access basic employment because they are controlled by socio-economic and cultural stigma. Most women who are victims of child marriage cannot be able to continue their schools especially within qualified schools or public schools. This is common phenomenon. ${ }^{63}$ Restriction on accessing to education indicates that they are more likely to have low social status and face difficulties in employment in which consequently suffer poverty and economic challenges. Bennett clarifies that education and employment has been neglected for this group. ${ }^{64}$ Women or girls should be promoted to have longer participation in formal education in order to eliminate structural gender discrimination.

As child marriage is closely related to socio-economic and cultural aspects including poverty, cultural practices and cultural-rooted related norms and values with respect to gender roles, there has been developed various theoretical framework to address to this issue. This includes 'social norm-based strategies'. Shawki envisages that the whole community should change their mindsets from blaming the victims and exclude them from educational and employment opportunities to provide more supportive system in terms of leadership skills and inspirations. Also, the community conducting child marriage must be seen as 'shameful' attitudes, ${ }^{65}$ not just for the victims.

Indonesia has to follow the Convention on the Right of the Child (CRC) and has ratified International standards like Convention on the Elimination of all forms of Discrimination Against Women (CEDAW) in 1985, Furthermore, it has enacted several laws including Human Rights Law No. 39 of 1999, the Law No. 23 of 2002 on the Protection on Children Rights and the Law No. 23 of 2004 on Domestic Violence.

${ }^{62}$ Davis, Postles, and Rosa, A girl's right to say no to marriage, pp. 20-2.

63 Matthew Gmalifo Mabefam and Kofi Ohene-Konadu, "Access to and Dropout of Girls from School: A Quantitative Analysis of The Effects of Marriage Arrangements on Girl-Child Education in Bolni”, Journal of Social Sciences, vol. 9, no. 3 (2013), pp. 119-26.

${ }^{64}$ Bennett, "Early Marriage, Adolescent Motherhood, and Reproductive Rights for Young Sasak Mothers in Lombok", p. 73.

65 Shawki, "Norm-Based Advocacy and Social Change: An Analysis of Advocacy Efforts to End Child Marriage", pp. 57-62. 
Regarding to Islamic Law perspective, child marriage is incompatible with common purpose of marriage in which to perform happy and harmonious life due to the pervailing concequences of such marriage. There are two considerations that Islam disapproves child marriage, namely no valid textual Islamic teaching (Islamic dogma), social and historical contexts as well. As previously described, Muslim scholars at least of South-Sulawesi generally argue that child marriage should be prevented. They prefer to see it within holistic approach because it is not merely regarding to health problems but also the forthcoming socio-economic ones including education and employment. According to progressive Islamic thinkers, Islamic doctrines should be incorporated with the contemporary contexts. ${ }^{66}$ If Child marriage ends up with lots of problems (mafsadat) for people and the community, so Islam never supports it.

\section{G. Concluding Remarks}

The prevalence of child marriage in South-Sulawesi Indonesia is persistent and it has been impacted on women and children's lives. The majority of community defines child marriage as the marriage conducted prior to the age of 16 for woman and of 19 for man as stipulated in the Marriage Law No.1 of 1974. Although they are fully aware of this, they still break the law for certain reasons such as premarital sexuality and the loss of virginity and other factors related to child marriage. Another understands child marriage as the marriage before 'akil balig'.

There are numbers of determinants for child marriage, namely cultural norms or values of shame ('siri) for family honour; family prestige and kinship; uneducated parents; economic burden for family and inconsistency in legislation. There is no clear explanation within religious teachings or Islamic Law which provokes the practice of child marriage because the purpose of marriage in Islam is to perform a happy and harmonious relationship among the couple. The use of the Prophet Muhammad's marriage to Aisha in the age of six as the fundamental basis for child marriage as indicated in hadith is invalid ( $($ ha' $i f$ ) because of rawi (transmitters) and including its matan (the content of hadith) which is

${ }^{66}$ Muzakki, "Current Debates in the Post-Soeharto Indonesian Islam”, pp. 321-66. 
Kasjim

contrary with historical evidences. Most Ulama in South-Sulawesi urge the parent to marry off their children if they are psychologically and physically strong or stable and economically independent. 


\section{Bibliography}

Abdullah, Hamid, Manusia Bugis Makassar, Jakarta: Inti Idayu Press, 1985.

Ali, Mukti et al., Fikih Kawin Anak: Membaca Ulang Teks Keagamaan Perkawinan Usia Anak-Anak, ed. by Lies Marcoes and Roland Gunawan, Jakarta: Yayasan Rumah Kita Bersama, 2015.

Al-Thabari, Abu Ja'far Muhammad bin Jarir, Ta'rikh al-Rusul wa'l Muluk, vol. IV, Egypt: Darul Ma'arif.

Arsal, Thriwaty, "Woman's Position in Undocumented Marriages", Komunitas: International Journal of Indonesian Society and Culture, vol. 6, no. 1, 2014, pp. 26-37 [http://dx.doi.org/10.15294/komunitas. v6i1.2947].

Baso, Zohra Andi, DA Tina, and S. Haerani, Kekerasan Terbadap Perempuan: Menghadang Langkah Perempuan, ed. by Faturochman, Yogyakarta: Pusat Studi Kependudukan dan Kebijakan, Universitas Gadjah Mada ; Ford Foundation, 2002.

Bedner, Adriaan and Stijn van Huis, "Plurality of marriage law and marriage registration for Muslims in Indonesia: a plea for pragmatism”, Utrecht Law Review, vol. 6, no. 2, 2010 [http:/ / dx.doi. org/10.18352/ulr.130].

Bennett, Linda Rae, "Early Marriage, Adolescent Motherhood, and Reproductive Rights for Young Sasak Mothers in Lombok", Wacana, vol. 15, no. 1, 2014, pp. 66-86 [http://dx.doi.org/10.17510/wjhi. v15i1.105].

Blackburn, Susan and Sharon Bessell, "Marriageable Age: Political Debates on Early Marriage in Twentieth-Century Indonesia", Indonesia, vol. 63, 1997.

Brown, Susan L., "Marriage and Child Well-Being: Research and Policy Perspectives", Journal of Marriage and Family, vol. 72, no. 5, 2010, pp. 1059-77 [http://dx.doi.org/10.1111/j.1741-3737.2010.00750.x].

Bukhārī, Muhammad ibn Ismā‘̄il, Shahih Bukhari, vol. v, Beirut: Dar alFikr, 1994.

Bunting, Annie, "Stages of Development: Marriage of Girls and Teens as an International Human Rights Issue”, Social \& Legal Studies, vol. 14, no. 
Kasjim

1, 2005, pp. 17-38 [http://dx.doi.org/10.1177/0964663905049524].

Choe, Minja Kim, Shyam Thapa, and Sulistinah Achmad, Early Marriage and Childbearing in Indonesia and Nepal, East-West Center Working Papers, no. 108-15, Honolulu: East-West Center, 2001.

Davis, Anthony, Claire Postles, and Giorgiana Rosa, A girl's right to say no to marriage: Working to end child marriage and keep girls in school, ed. by Anna Brown, Woking: Plan International, 2013.

Gangoli, Geetanjali, Melanie McCarry, and Amina Razak, "Child Marriage or Forced Marriage? South Asian Communities in North East England", Children \& Society, vol. 23, no. 6, 2009, pp. 418-29 [http:// dx.doi.org/10.1111/j.1099-0860.2008.00188.x].

Hamid, Abu, Syekh Yusuf Makassar: Seorang Ulama, Sufi dan Pejuang, Jakarta: Yayasan Obor Indonesia, 1994.

Hanafi, Yusuf, "Pengendalian Perkawinan Dini (Child Marriage) Melalui Pengembangan Modul Pendidikan Penyadaran Hukum: Studi Kasus pada Masyarakat Subkultur Madura di Daerah Tapal Kuda, Jawa Timur", PALASTREN Jurnal Studi Gender, vol. 8, no. 2, 2016, pp. 399-422 [http://dx.doi.org/10.21043/palastren.v8i2.972].

Harding, Claire, "The Influence of the 'Decadent West': Discourses of the Mass Media on Youth Sexuality in Indonesia Workers", Intersections: Gender and Sexuality in Asia and the Pacific, no. 18, 2008.

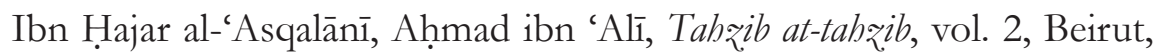
Lubnan: Dar Sader, 1968.

Jones, Gavin W., Changing Marriage Patterns in Asia, ARI Working Paper Series, no. 131, Singapore: NUS, 2010.

Jones, Gavin W. and Wei-Jun Jean Yeung, "Marriage in Asia", Journal of Family Issues, vol. 35, no. 12, 2014, pp. 1567-83 [http://dx.doi. org/10.1177/0192513X14538029].

Kamal, S.M. Mostafa et al., "Child Marriage in Bangladesh: Trends and Determinants", Journal of Biosocial Science, vol. 47, no. 1, 2015, pp. 120-39 [http://dx.doi.org/10.1017/S0021932013000746].

Komaruddin Hidayat, "Arkoun dan Tradisi Hermeneutika", in Tradisi, Kemodernan, dan Metamodernisme: Memperbincangkan Pemikiran Mohammed Arkoun, ed. by Johan H. Meuleman, Yogyakarta: LKiS, 
1996.

Latif, Abdul, "Politik Perkawinan dan Pola Pewarisan Kekuasaan di Konfederasi Ajatappareng, Sulawesi Selatan", Paramita: Historical Studies Journal, vol. 24, no. 1, 2014 [http://dx.doi.org/10.15294/ paramita.v24i1.2913].

Lindsey, Tim, "An Overview of Indonesian Law", in Indonesia: Law and Society, ed. by Tim Lindsey, New South Wales: The Federation Press, 2008.

Mabefam, Matthew Gmalifo and Kofi Ohene-Konadu, "Access to and Dropout of Girls from School: A Quantitative Analysis of The Effects of Marriage Arrangements on Girl-Child Education in Bolni”, Journal of Social Sciences, vol. 9, no. 3, 2013, pp. 119-26 [http:// dx.doi.org/10.3844/jssp.2013.119.126].

Makin, Al, "Islamic Acehnese Identity, Sharia, and Christianization Rumor: A Study of the Narratives of the Attack on the Bethel Church in Penauyong Banda Aceh", Journal of Indonesian Islam, vol. 10, no. 1, 2016, pp. 1-36 [http://dx.doi.org/10.15642/JIIS.2016.10.1.1-36].

Marcoes, Lies, "Indri: Tidak Mau Nikah Maunya Sekolah", in Kesaksian Pengantin Bocah, ed. by Lies Marcoes and Fadilla Dwianti Putri, Jakarta: Yayasan Rumah Kita Bersama, 2016.

Marcoes, Lies and Fadilla Dwianti Putri, "Yunita: Menikah Karena Capek Bantu Ibu", in Kesaksian Pengantin Bocah, ed. by Lies Marcoes and Fadilla Dwianti Putri, Jakarta: Yayasan Rumah Kita Bersama, 2016.

Mawan, Nurum Mukharum, "Mengapa Kalian Ingin Memisahkan Kami? Cerita Cinta Syekh Puji-Lutfiana Ulfa", Cahaya Sura, 6 Nov 2008, https://cahayasura.wordpress.com/2008/11/06/mengapa-kalianingin-memisahkan-kami-cerita-cinta-syekh-puji-lutfiana-ulfa/, accessed 13 Aug 2016.

Muzakki, Akh, "Current Debates in the Post-Soeharto Indonesian Islam: Examining the Intellectual Base of Liberal and Anti-liberal Islamic Movement", Al-Jami'ah: Journal of Islamic Studies, vol. 45, no. 2, 2007, pp. 321-66 [http://dx.doi.org/10.14421/ajis.2007.452.321-366].

Nour, N.M., "Health Consequences of Child Marriage in Africa", Emerging Infectious Disease journal - CDC, vol. 12, no. 11, 2006 [http:// 
dx.doi.org/10.3201/eid1211.060510].

Nurlaelawati, Euis, "For the Sake of Protecting Religion: Apostasy and its Judicial Impact on Muslim's Marital Life in Indonesia", Journal of Indonesian Islam, vol. 10, no. 1, 2016, pp. 89-112 [http://dx.doi. org/10.15642/JIIS.2016.10.1.89-112].

Perkawinan Usia Anak di Indonesia 2013 dan 2015, Jakarta: Direktorat Statistik Kesejahteraan Rakyat, BPS, 2016.

Phillips, Anne and Moira Dustin, "UK Initiatives on Forced Marriage: Regulation, Dialogue and Exit", Political Studies, vol. 52, no. 3, 2004, pp. 531-51 [http://dx.doi.org/10.1111/j.1467-9248.2004.00494.x].

Platt, Maria, "'It's Already Gone Too Far': Women and the Transition into Marriage in Lombok, Indonesia", The Asia Pacific Journal of Anthropology, vol. 13, no. 1, 2012, pp. 76-90 [http://dx.doi.org/10. 1080/14442213.2011.636063].

Santhya, K.G., "Early marriage and sexual and reproductive health vulnerabilities of young women: a synthesis of recent evidence from developing countries", Current Opinion in Obstetrics and Gynecology, vol. 23, no. 5, 2011.

Shawki, Noha, "Norm-Based Advocacy and Social Change: An Analysis of Advocacy Efforts to End Child Marriage", Social Alternatives, vol. 34, no. 4, 2015.

Svanemyr, Joar et al., "Preventing Child Marriages: First International Day of the Girl Child "My Life, My Right, End Child Marriage", Reproductive Health, vol. 9, 2012, p. 31 [http://dx.doi.org/10.1186/1742-47559-31].

Utomo, Ariane J., "Marrying Up? Trends in Age and Education Gaps Among Married Couples in Indonesia", Journal of Family Issues, vol. 35, no. 12, 2014, pp. 1683-706 [http://dx.doi. org/10.1177/0192513X14538023].

Windyanggiva, Qanita, "Rani: Menikah Karena Dilarang Pacaran”, in Kesaksian Pengantin Bocah, ed. by Lies Marcoes and Fadilla Dwianti Putri, Jakarta: Yayasan Rumah Kita Bersama, 2016. 